Supporting Information

\title{
Plane-Selective Coating of $\mathrm{Li}_{2} \mathrm{SnO}_{3}$ on $\mathrm{Li}\left[\mathrm{Ni}_{x} \mathrm{Co}_{1}\right.$ -
}

\section{x $\mathrm{O}_{2}$ for High Power Li-Ion Batteries}

Hanseul Kim, ${ }^{1+}$ Garam Choi, ${ }^{1+}$ Seongmin Kim, ${ }^{1+}$ Donghoon Lee, ${ }^{1,2}$ Sung Wook Doo, ${ }^{1}$

Jungwon Park, ${ }^{1,2}$ Won Bo Lee $e^{1 *}$ and Kyu Tae Lee $e^{1 *}$

1 School of Chemical and Biological Engineering, Institute of Chemical Processes, Seoul

National University, Seoul, 08826, Republic of Korea.

2 Center for Nanoparticle Research, Institute for Basic Science (IBS), Seoul, 08826, Republic of Korea

\section{Corresponding Author}

*Won Bo Lee: wblee@snu.ac.kr.*Kyu Tae Lee: ktlee@snu.ac.kr 


\section{EXPERIMENTAL SECTION}

\section{Material synthesis}

Bare $\mathrm{Li}\left[\mathrm{Ni}_{\mathrm{x}} \mathrm{Co}_{1-\mathrm{x}}\right] \mathrm{O}_{2}$, Sn-doped $\mathrm{Li}\left[\mathrm{Ni}_{\mathrm{x}} \mathrm{Co}_{1-\mathrm{x}}\right] \mathrm{O}_{2}$, and plane-selectively $\mathrm{Li}_{2} \mathrm{SnO}_{3}$ coated $\mathrm{Li}\left[\mathrm{Ni}_{\mathrm{x}} \mathrm{Co}_{1-\mathrm{x}}\right] \mathrm{O}_{2}(\mathrm{x}=0$ and 0.5$)$ powders were synthesized using a simple sol-gel method. $\mathrm{LiNO}_{3}$ (Sigma Aldrich), $\mathrm{Ni}\left(\mathrm{NO}_{3}\right)_{2} \cdot 6 \mathrm{H}_{2} \mathrm{O}$ (Sigma Aldrich), $\mathrm{Co}\left(\mathrm{NO}_{3}\right)_{2} \cdot 6 \mathrm{H}_{2} \mathrm{O}$ (Sigma Aldrich) and $\mathrm{SnCl}_{2}$ (Alfa Aesar) precursors were dissolved in ethanol. The molar ratios of precursors were $\mathrm{Li}: \mathrm{Ni}_{\mathrm{x}} \mathrm{Co}_{1-\mathrm{x}}: \mathrm{Sn}=1.03(1+\mathrm{y}): 1-\mathrm{y}: \mathrm{y}$ where $\mathrm{y}=0,0.01,0.02$, and 0.05 . Citric acid (Sigma Aldrich) as a chelating agent was added as much as the total molar amount of all cations. The solutions were stirred for 6 hours at $80^{\circ} \mathrm{C}$ to obtain transparent gels, followed by being dried in a vacuum oven overnight to exterminate solvents. Homogenously mixed powders were heated in air at $300^{\circ} \mathrm{C}$ for 5 hours. Then they were reheated in the air for 10 hours at $700^{\circ} \mathrm{C}$ to obtain bare $\mathrm{LiCoO}_{2}$ and $\mathrm{Sn}$-doped $\mathrm{LiCoO}_{2}$, at $900^{\circ} \mathrm{C}$ to obtain plane-selective $\mathrm{LiCoO}_{2}-\mathrm{Li}_{2} \mathrm{SnO}_{3}$ coreshells, and at $800^{\circ} \mathrm{C}$ to obtain plane-selective $\mathrm{Li}\left[\mathrm{Ni}_{0.5} \mathrm{Co}_{0.5}\right] \mathrm{O}_{2}-\mathrm{Li}_{2} \mathrm{SnO}_{3}$ core-shells. The heating rate was $10^{\circ} \mathrm{C} \min ^{-1}$ for all samples and the cooling rate was about $1{ }^{\circ} \mathrm{C} \mathrm{min}-1$ for plane-selective $\mathrm{Li}\left[\mathrm{Ni}_{\mathrm{x}} \mathrm{Co}_{1-\mathrm{x}}\right] \mathrm{O}_{2}-\mathrm{Li}_{2} \mathrm{SnO}_{3}$ core-shells.

Conventional sol-gel derived $\mathrm{Li}_{2} \mathrm{SnO}_{3}$-coated $\mathrm{LiCoO}_{2}$ was obtained according to the previously reported method. ${ }^{1,}{ }^{2} \mathrm{LiNO}_{3}$ (Sigma Aldrich) and Tin(IV) 2-ethylhexano diisopropoxide (Alfa Aesar) were dissolved in 2-Propanol (Alfa Aesar) with the molar ratio of $\mathrm{Li}: \mathrm{Sn}=2: 1$. Bare $\mathrm{LiCoO}_{2}$ powders were dispersed in the solution with the molar ratio of $\mathrm{Li}_{2} \mathrm{SnO}_{3}: \mathrm{LiCoO}_{2}=0.05: 1$. The mixtures were dried using a rotary evaporator at $50^{\circ} \mathrm{C}$ to remove solvents. Then, powders were heated in air at $700^{\circ} \mathrm{C}$ for 6 hours. 


\section{Material characterization}

X-ray diffraction (XRD) patterns of powders and electrodes were obtained using a Bruker D2 PHASER with $\mathrm{Cu} \mathrm{K \alpha}$ radiation $(\lambda=1.5418 \AA)$ operated in the $2 \theta$ range of $10-80^{\circ}$. The lattice parameters and the occupancies of atoms were obtained from full pattern matching refinements using the TOPAS program. TEM samples were examined using a high-resolution transmission electron microscope (HR-TEM, STEM, JEOL ARM-200F). Cross-sectional thin STEM specimens were obtained using the Ar ion slicer (JEOL EM-09100 IS). FE-SEM images were obtained using an FE-SEM (JSM-6701F, JEOL Ltd).

\section{Electrochemical characterization}

Active materials were mixed with carbon black (Super P, TIMCAL) and polyvinylidene fluoride (PVdF, KF-1100, Kureha) in a weight ratio of 8:1:1. The slurry was cast onto a current collector (Al foil). The electrodes were dried at $120^{\circ} \mathrm{C}$ overnight in a vacuum oven. The mass loading of active materials in electrodes is $5.5-6 \mathrm{mg} \mathrm{cm}^{-2}$. The electrochemical performance of half cells was evaluated using 2032 coin cells with a Li metal (Honjo metal Co. Ltd.) and 1.3 $\mathrm{M} \mathrm{LiPF}_{6}$ in ethylene carbonate, ethylmethyl carbonate and dimethyl carbonate $(30: 40: 30$ vol.\%, Soulbrain Co. Ltd.). Galvanostatic experiments of the electrodes were performed at a

current density of $1 \mathrm{C}$ rate $\left(160 \mathrm{~mA} \mathrm{~g}^{-1}\right)$ for $\mathrm{LiCoO}_{2}$ and $0.5 \mathrm{C}$ rate $\left(180 \mathrm{~mA} \mathrm{~g}^{-1}\right)$ for $\mathrm{Li}\left[\mathrm{Ni}_{0.5} \mathrm{Co}_{0.5}\right] \mathrm{O}_{2}$ after precycling at a $0.1 \mathrm{C}$ rate using WBCS 3000 (WonATech, Korea) at 25 and $60^{\circ} \mathrm{C}$. Cells were cycled between 3.0-4.5 V and 2.7-4.4 V (vs. $\mathrm{Li}^{-} \mathrm{Li}^{+}$) for $\mathrm{LiCoO}_{2}$ and $\mathrm{Li}\left[\mathrm{Ni}_{0.5} \mathrm{Co}_{0.5}\right] \mathrm{O}_{2}$, respectively. Electrochemical impedance spectroscopy (EIS) was measured using $\mathrm{LiCoO}_{2} / \mathrm{LiCoO}_{2}$ symmetric cells with an amplitude of $5 \mathrm{mV}$ over a frequency range of 
0.005 to $100 \mathrm{kHz}$. The electrodes used for $\mathrm{LiCoO}_{2} / \mathrm{LiCoO}_{2}$ symmetric cells were charged upto $4.05 \mathrm{~V}\left(\mathrm{vs} . \mathrm{Li} / \mathrm{Li}^{+}\right)$after $1^{\text {st }}$ precycle.

\section{Computational methods}

The DFT calculations were performed using the projector augmented wave (PAW) method and Generalized Gradient Approximation (GGA-PW91) exchange-correlation functional as implemented in Vienna ab initio simulation package (VASP). ${ }^{3-5} \mathrm{Li} 2 s$, Co $4 s$ and $3 d$, Sn $5 s$ and $5 p$ and $\mathrm{O} 2 s$ and $2 p$ electrons were treated as valence electrons. All the structures consist of 48 atoms in a $2 \times 2$ supercell, respectively. We have substituted $1 \mathrm{Co}$ atom with $1 \mathrm{Sn}$ atom in a supercell, leading to solid solution composition of $\mathrm{Li}\left[\mathrm{Sn}_{0.08} \mathrm{Co}_{0.92}\right] \mathrm{O}_{2}$. Free energies were computed from the results of DFT calculations of these structures. ${ }^{6-8}$ Helmholtz free energies $(F)$ were calculated using lattice dynamics based on DFT and partition functions $(Z)$ of phonon frequencies, where $\mathrm{F}=-\mathrm{kBT} \ln \mathrm{Z}$. The calculations were performed using phonopy package and detail formulations were described in papers by the developers. ${ }^{8,9}$ 


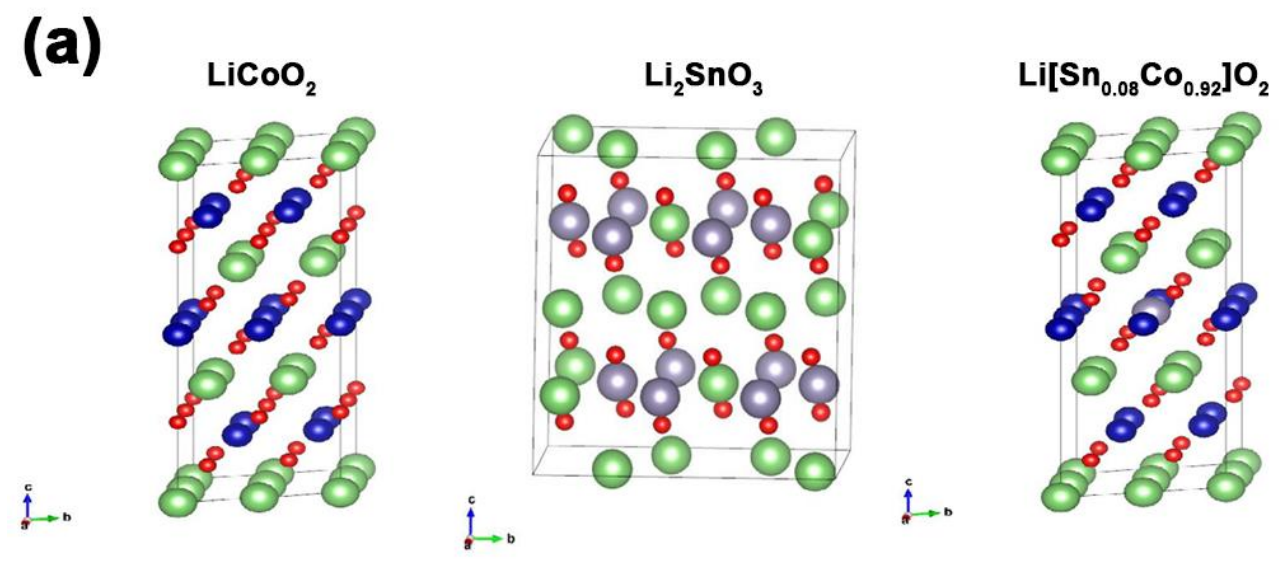

(b)

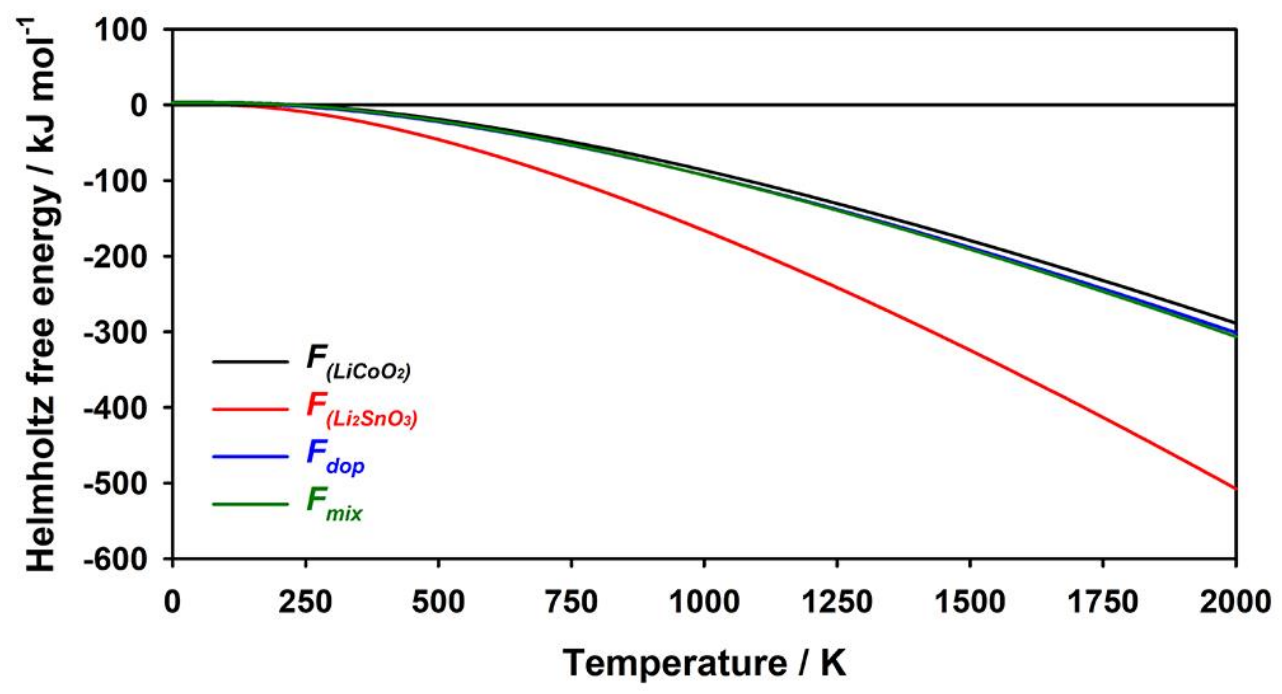

Figure S1. (a) Crystal structures of $\mathrm{LiCoO}_{2}, \mathrm{Li}_{2} \mathrm{SnO}_{3}$ and $\mathrm{Li}\left[\mathrm{Sn}_{0.08} \mathrm{Co}_{0.92}\right] \mathrm{O}_{2}$ for DFT calculations. (b) Theoretical Helmholtz free energy variations of $\mathrm{LiCoO}_{2}, \mathrm{Li}_{2} \mathrm{SnO}_{3}$ and $\mathrm{Li}\left[\mathrm{Sn}_{0.08} \mathrm{Co}_{0.92}\right] \mathrm{O}_{2}$ with increasing temperature. 
(a)

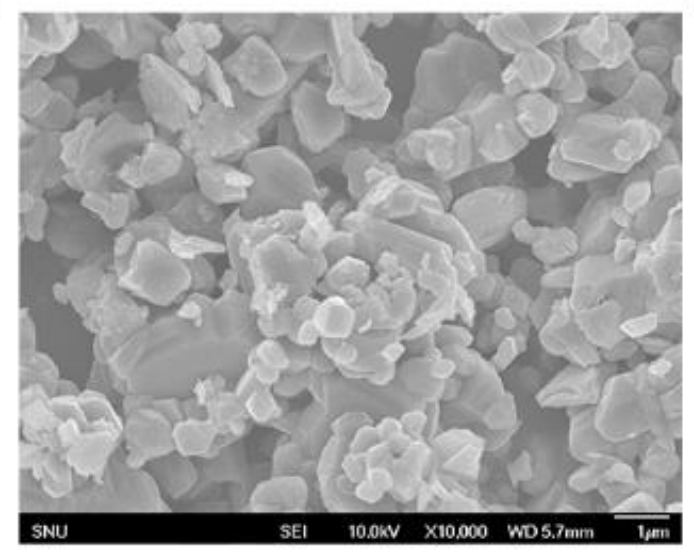

(c)

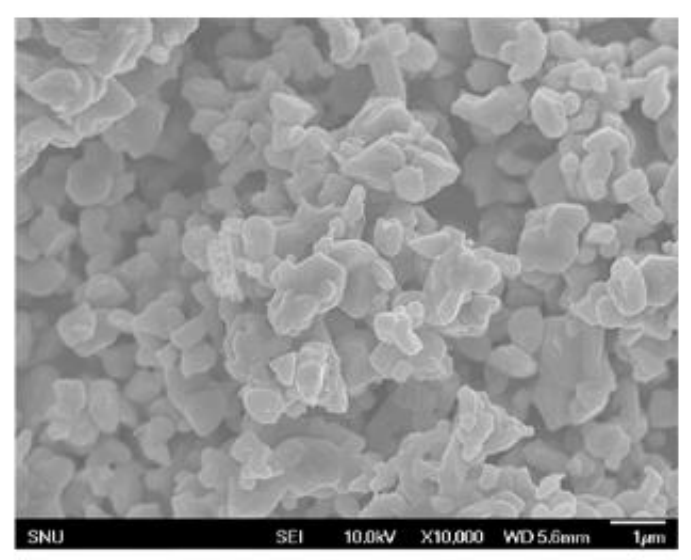

(b)

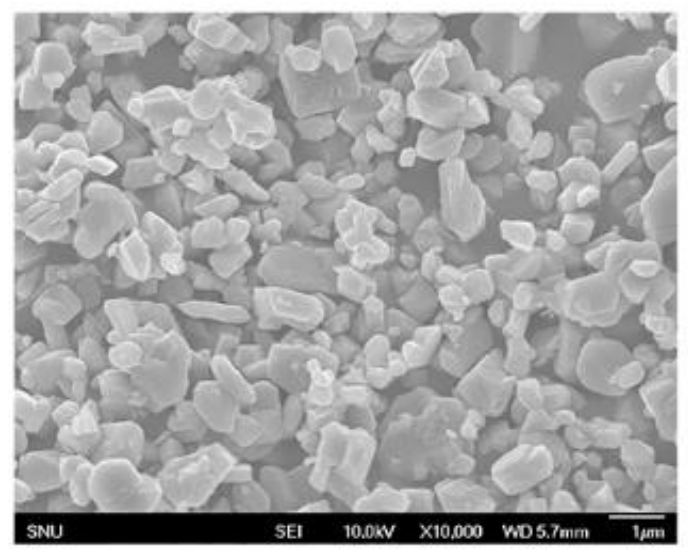

(d)

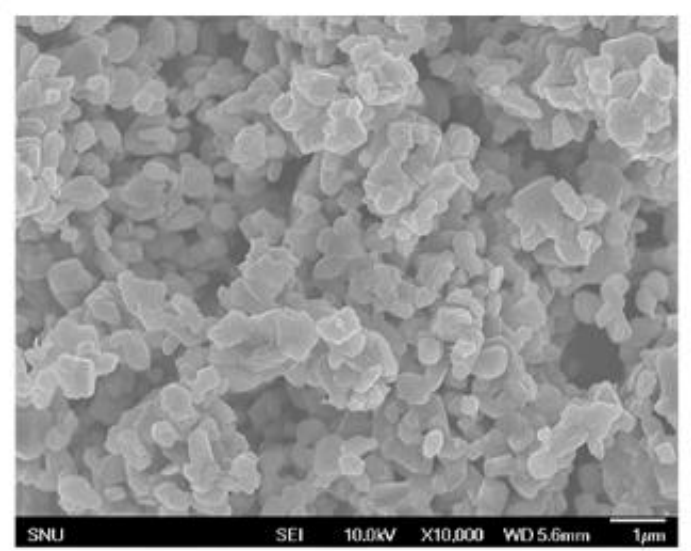

Figure S2. SEM images of $\mathrm{xLi}_{2} \mathrm{SnO}_{3}+(1-\mathrm{x}) \mathrm{LiCoO}_{2}$, where $\mathrm{x}=$ (a) 0 , (b) 0.01 (c) 0.02 (d) 0.05 


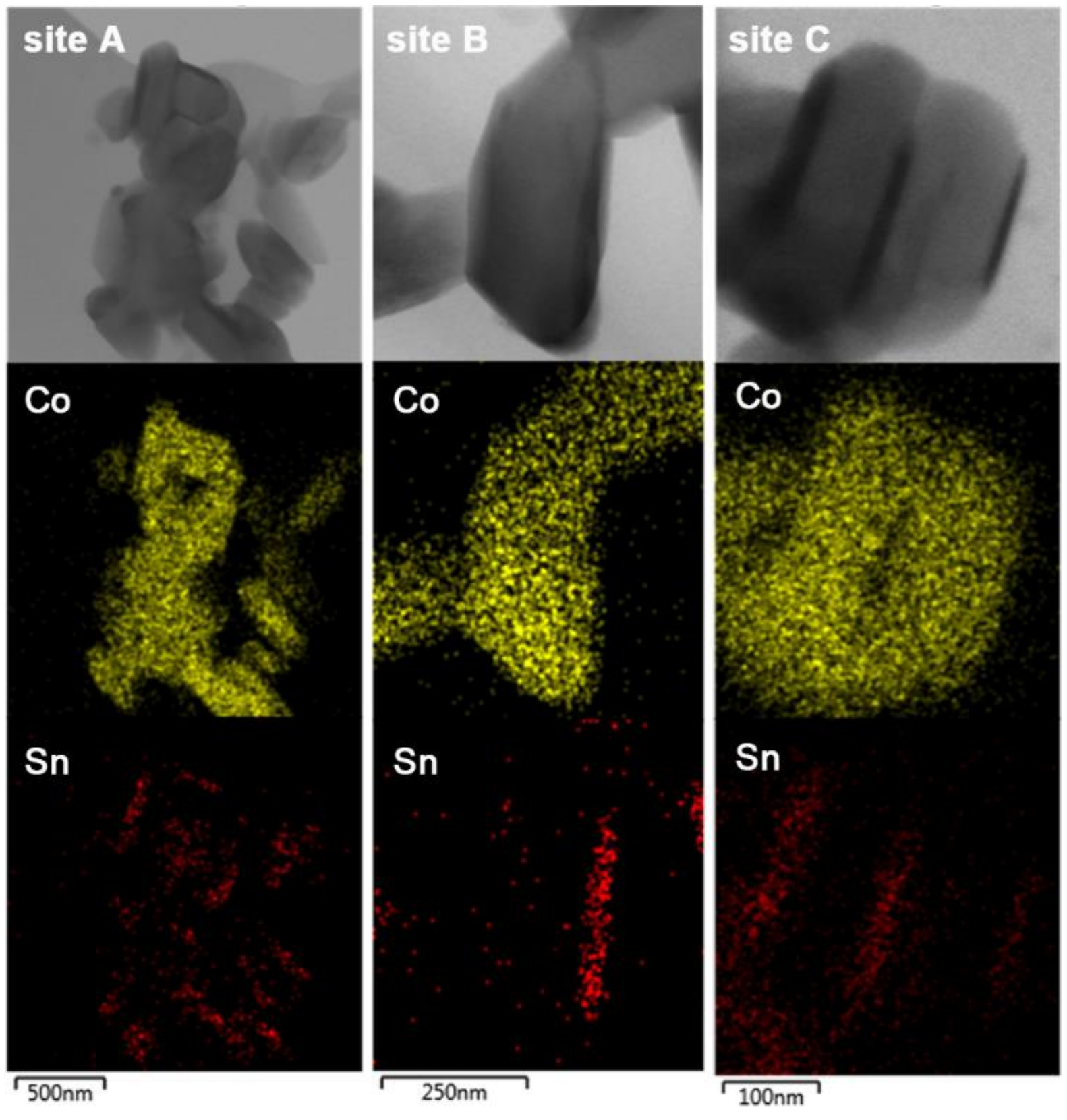

Figure S3. Cross-sectional STEM and corresponding EDS mapping images of planeselectively $\mathrm{Li}_{2} \mathrm{SnO}_{3}$-coated $\mathrm{LiCoO}_{2}$ powders heated at $900^{\circ} \mathrm{C}$ 


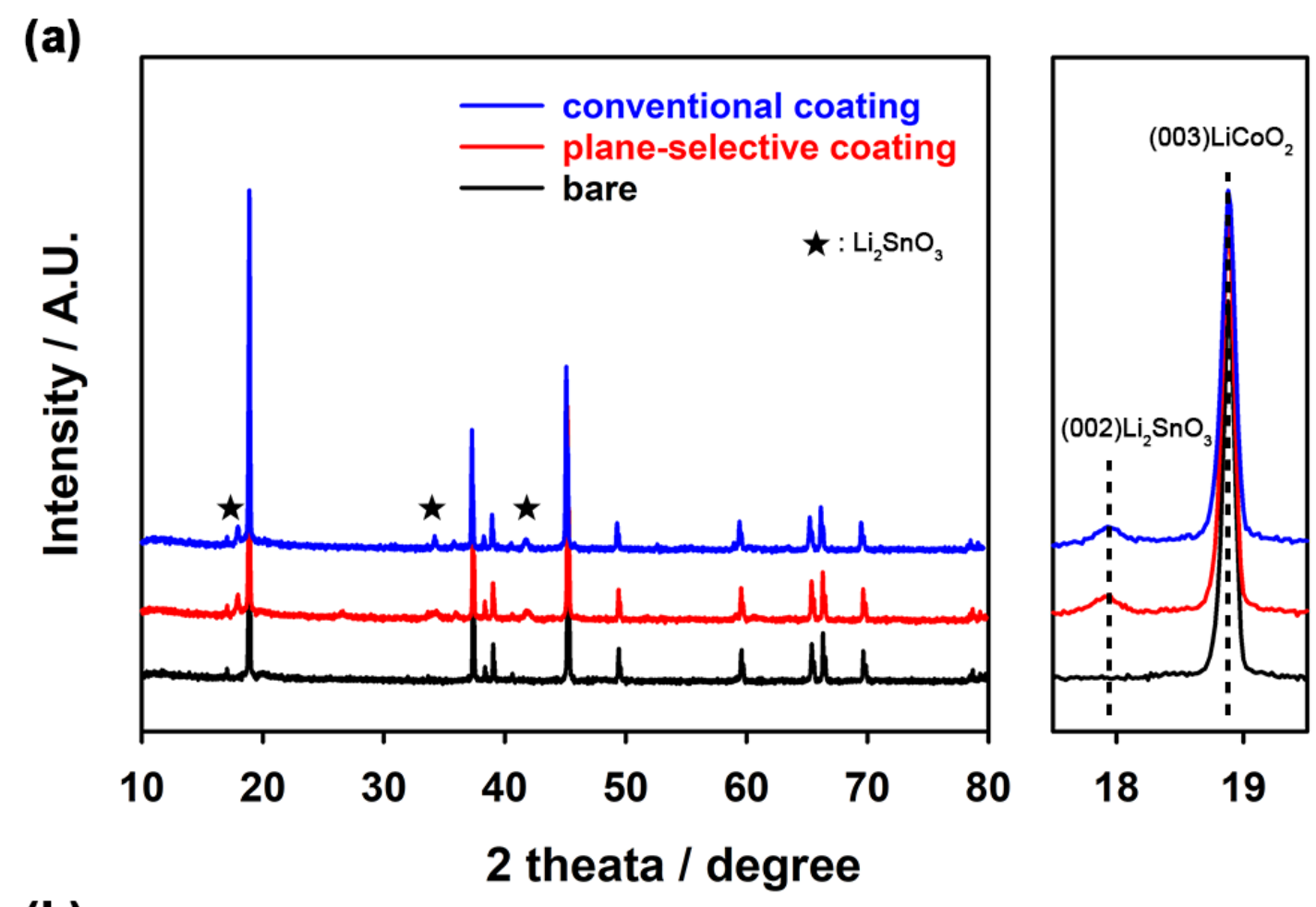

(b)

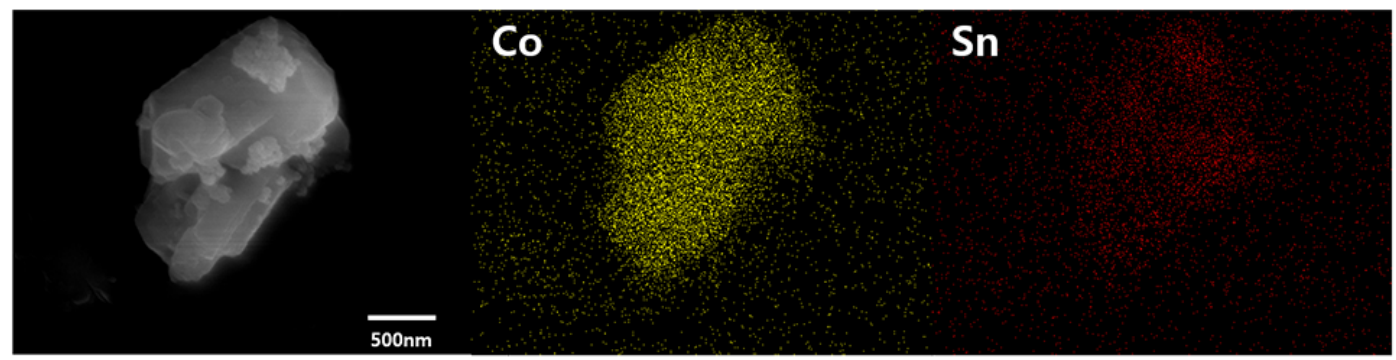

Figure S4. (a) Powder XRD patterns of bare, plane-selectively and conventionally $\mathrm{Li}_{2} \mathrm{SnO}_{3}$ coated $\mathrm{LiCoO}_{2}$. (b) SEM-EDS mapping images of conventional sol-gel derived $\mathrm{Li}_{2} \mathrm{SnO}_{3}-$ coated $\mathrm{LiCoO}_{2}$ powders. 

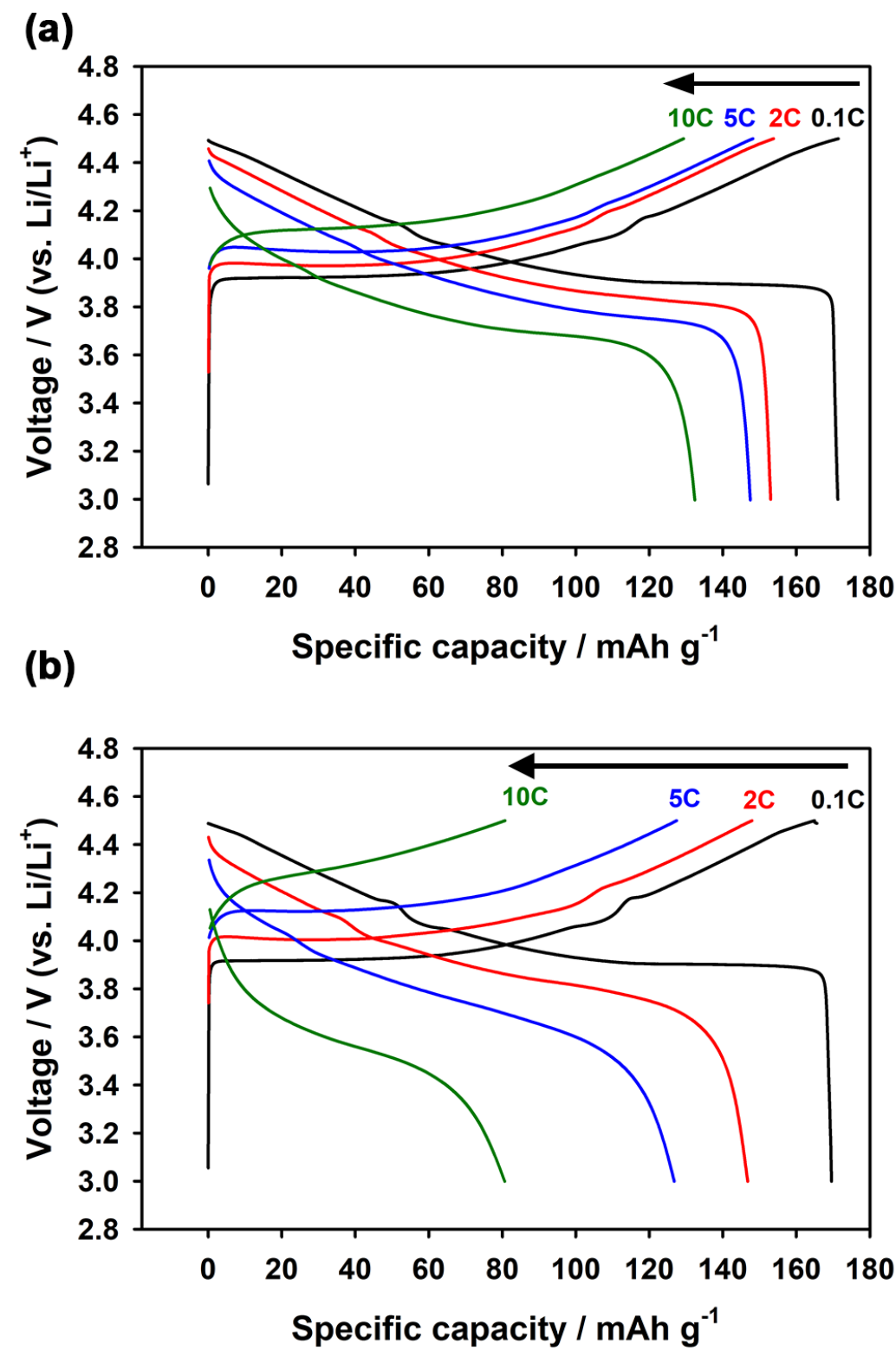

Figure S5. Voltage profiles of (a) plane-selective and (b) conventional sol-gel derived $\mathrm{Li}_{2} \mathrm{SnO}_{3}$-coated $\mathrm{LiCoO}_{2}$ at various C-rates 
(a)

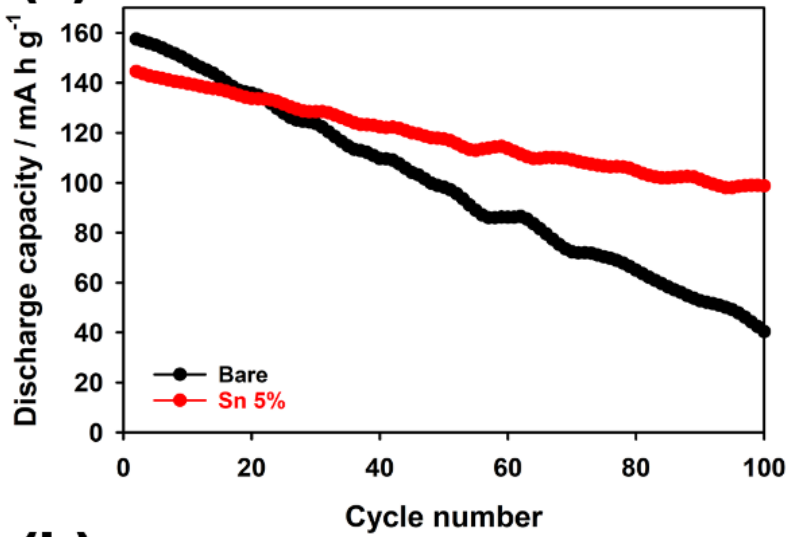

(b)

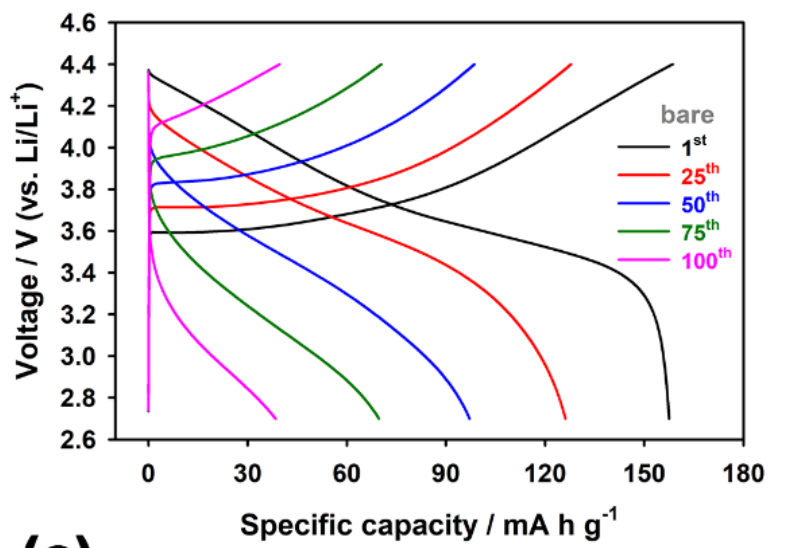

(c)

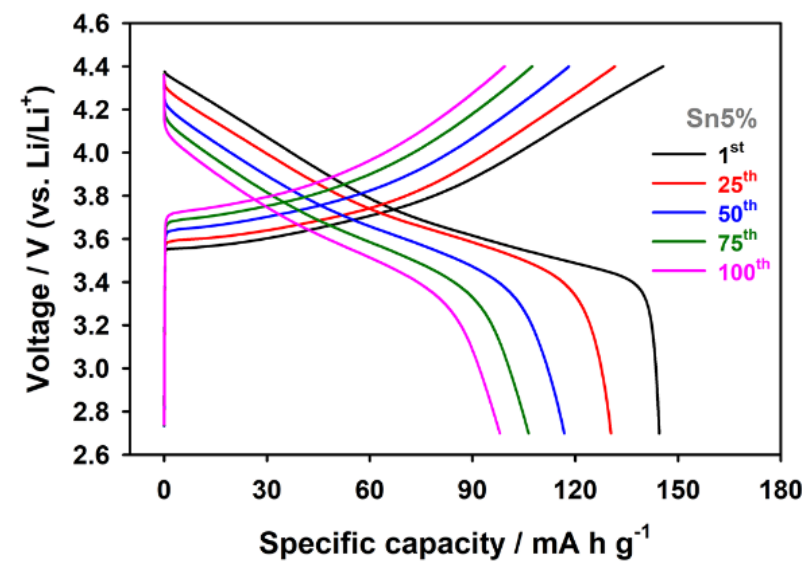

Figure S6. (a) Cycle performances of bare $\mathrm{Li}\left[\mathrm{Ni}_{0.5} \mathrm{Co}_{0.5}\right] \mathrm{O}_{2}$ and plane-selective $\mathrm{LiCoO}_{2}$ $\mathrm{Li}_{2} \mathrm{SnO}_{3}$ core-shell. Corresponding voltage profiles of (b) bare (c) 5 at $\% \mathrm{Li}_{2} \mathrm{SnO}_{3}$-coated $\mathrm{LiCoO}_{2}$ at various cycle numbers. 

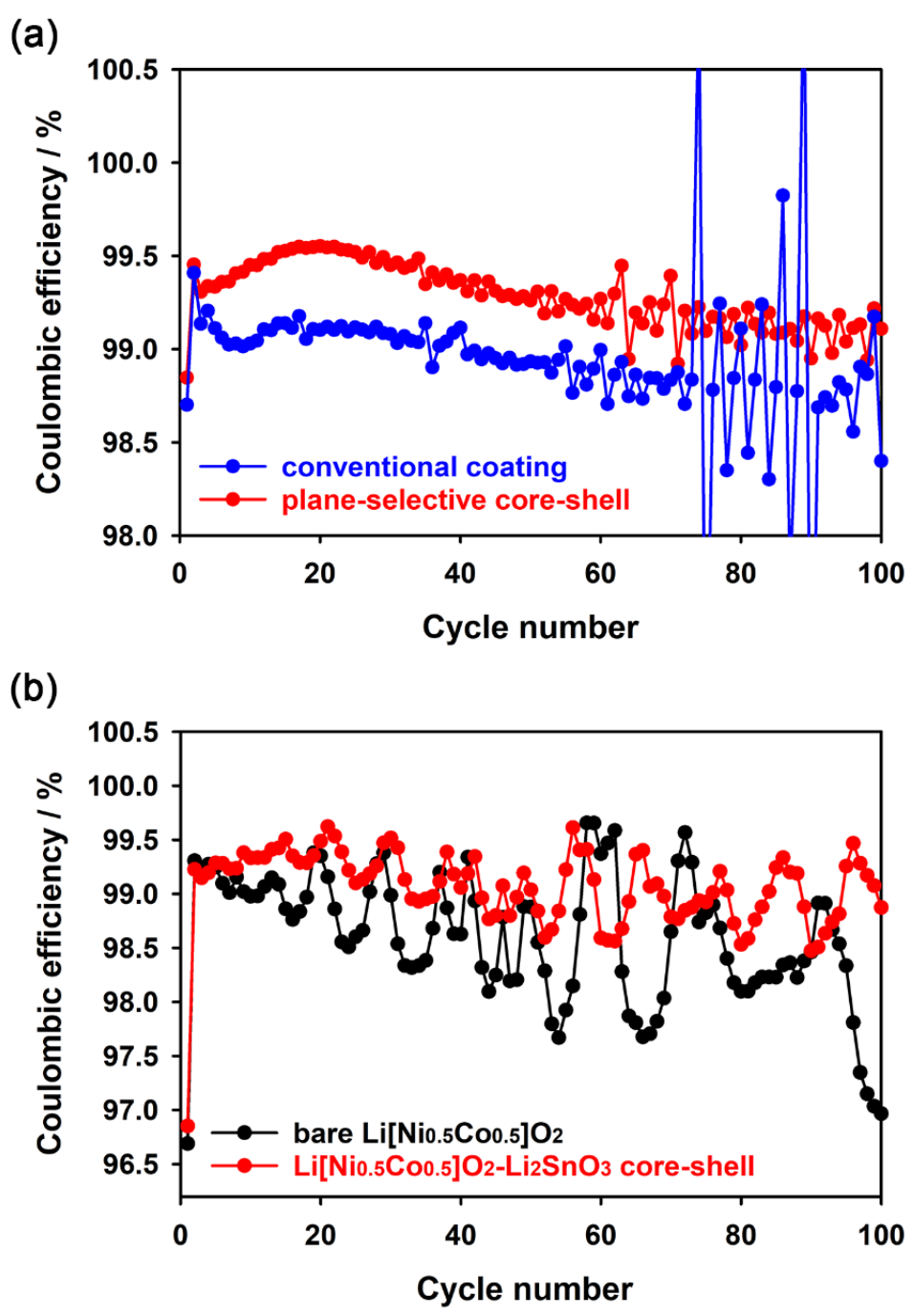

Figure S7. (a) Coulombic efficiencies of the plane-selective $\mathrm{LiCoO}_{2}-\mathrm{Li}_{2} \mathrm{SnO}_{3}$ core-shell and conventional sol-gel derived $\mathrm{Li}_{2} \mathrm{SnO}_{3}$-coated $\mathrm{LiCoO}_{2}$ during cycling. (b) Coulombic efficiencies of bare $\mathrm{Li}\left[\mathrm{Ni}_{0.5} \mathrm{Co}_{0.5}\right] \mathrm{O}_{2}$ and the plane-selective $\mathrm{Li}\left[\mathrm{Ni}_{0.5} \mathrm{Co}_{0.5}\right] \mathrm{O}_{2}-\mathrm{Li}_{2} \mathrm{SnO}_{3}$ coreshell during cycling. 
(a)

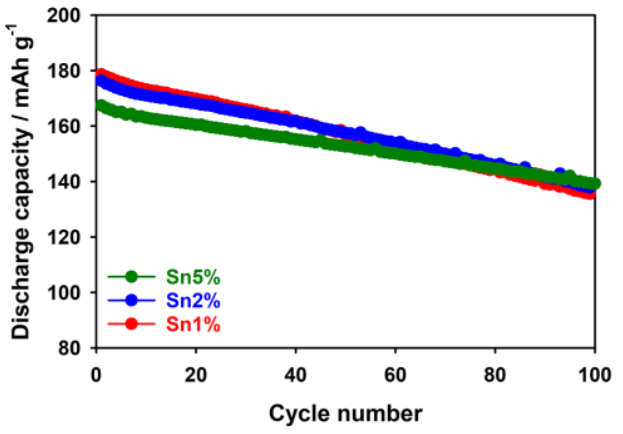

(b)

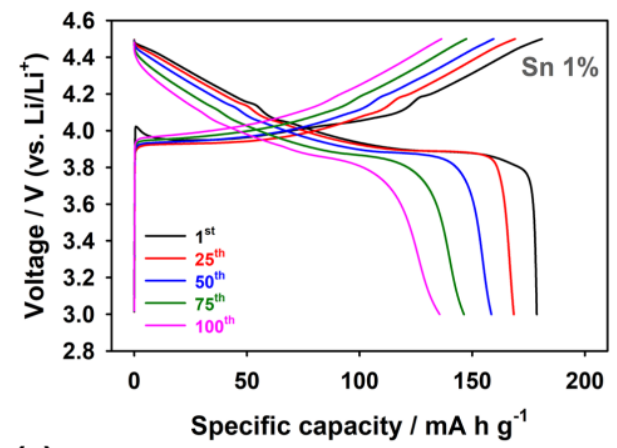

(c)

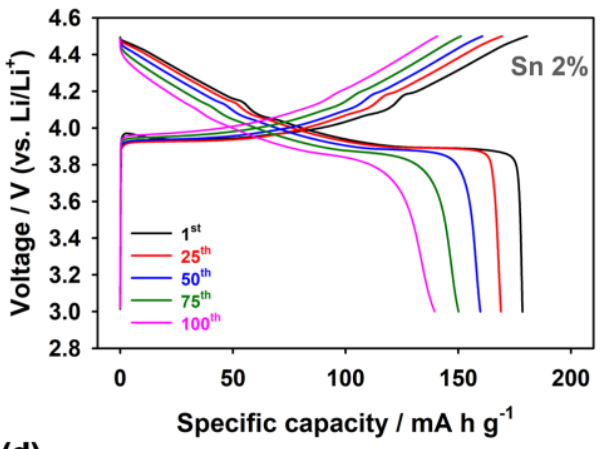

(d)

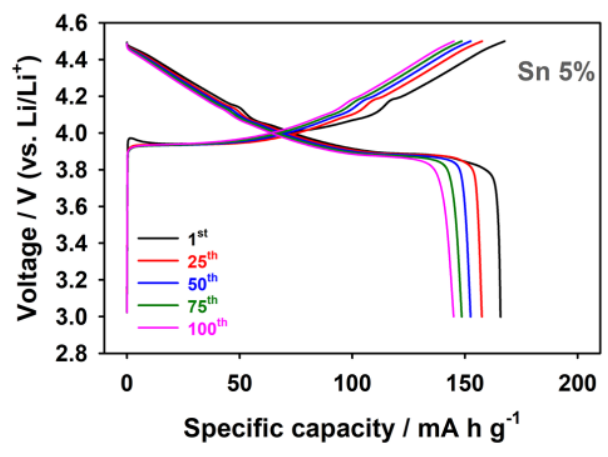

Figure S8. (a) Cycle performances of bare $\mathrm{LiCoO}_{2}$ and plane-selective $\mathrm{Li}_{2} \mathrm{SnO}_{3}$-coated $\mathrm{LiCoO}_{2}$ with various $\mathrm{Sn}$ compositions. Corresponding voltage profiles of (b) 1 at $\%$, (c) 2 at $\%$ and (d) 5 at $\% \mathrm{Li}_{2} \mathrm{SnO}_{3}$-coated $\mathrm{LiCoO}_{2}$ at various cycle numbers. 


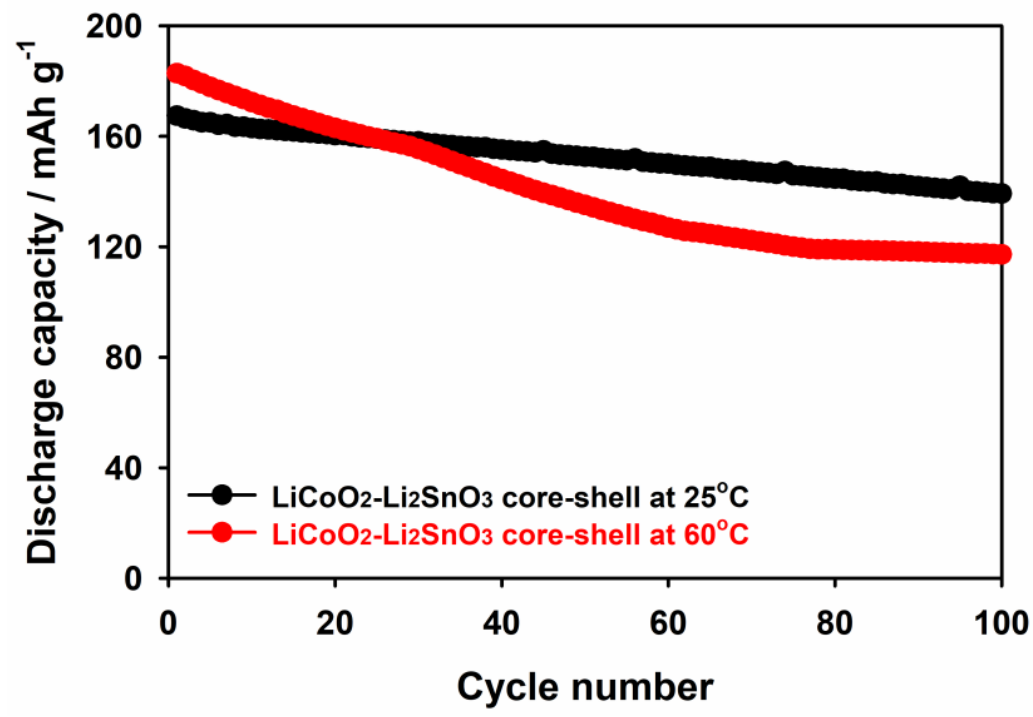

Figure S9. Cycle performances of the plane-selective $\mathrm{LiCoO}_{2}-\mathrm{Li}_{2} \mathrm{SnO}_{3}$ core-shell under the condition of the $1 \mathrm{C}$ rate at $25^{\circ} \mathrm{C}$ and $60^{\circ} \mathrm{C}$. 


\section{REFERENCES}

(1) Mou, J.; Deng, Y.; Song, Z.; Zheng, Q.; Lam, K. H.; Lin, D., Excellent rate capability and cycling stability in $\mathrm{Li}^{+}$-conductive $\mathrm{Li}_{2} \mathrm{SnO}_{3}$-coated $\mathrm{LiNi}_{0.5} \mathrm{Mn}_{1.5} \mathrm{O}_{4}$ cathode materials for lithium-ion batteries. Dalton Trans. 2018, 47 (20), 7020-7028.

(2) Hu, G.; Zhang, M.; Wu, L.; Peng, Z.; Du, K.; Cao, Y., Enhanced Electrochemical Performance of $\mathrm{LiNi}_{0.5} \mathrm{Co}_{0.2} \mathrm{Mn}_{0.3} \mathrm{O}_{2}$ Cathodes Produced via Nanoscale Coating of $\mathrm{Li}^{+}$-Conductive $\mathrm{Li}_{2} \mathrm{SnO}_{3}$. Electrochim. Acta 2016, 213, 547-556.

(3) Kresse, G.; Joubert, D., From ultrasoft pseudopotentials to the projector augmentedwave method. Phys. Rev. B 1999, 59 (3), 1758-1775.

(4) Perdew, J. P.; Wang, Y., Accurate and simple analytic representation of the electrongas correlation energy. Phys. Rev. B 1992, 45 (23), 13244-13249.

(5) Kresse, G.; Hafner, J., Ab initio molecular dynamics for liquid metals. Phys. Rev. B 1993, $47(1), 558-561$.

(6) Hu, L.; Xiong, Z.; Ouyang, C.; Shi, S.; Ji, Y.; Lei, M.; Wang, Z.; Li, H.; Huang, X.; Chen, L., Ab initiostudies on the stability and electronic structure of $\mathrm{LiCoO}_{2}(003)$ surfaces. Phys. Rev. B 2005, 71 (12), 125433.

(7) Skelton, J. M.; Burton, L. A.; Oba, F.; Walsh, A., Chemical and Lattice Stability of the Tin Sulfides. J. Phys. Chem. C 2017, 121 (12), 6446-6454.

(8) Skelton, J. M.; Parker, S. C.; Togo, A.; Tanaka, I.; Walsh, A., Thermal physics of the lead chalcogenides $\mathrm{PbS}, \mathrm{PbSe}$, and PbTe from first principles. Phys. Rev. $B$ 2014, 89 (20), 205203.

(9) Kramer, D.; Ceder, G., Tailoring the Morphology of $\mathrm{LiCoO}_{2}$ : A First Principles Study. Chem. Mater. 2009, 21 (16), 3799-3809. 